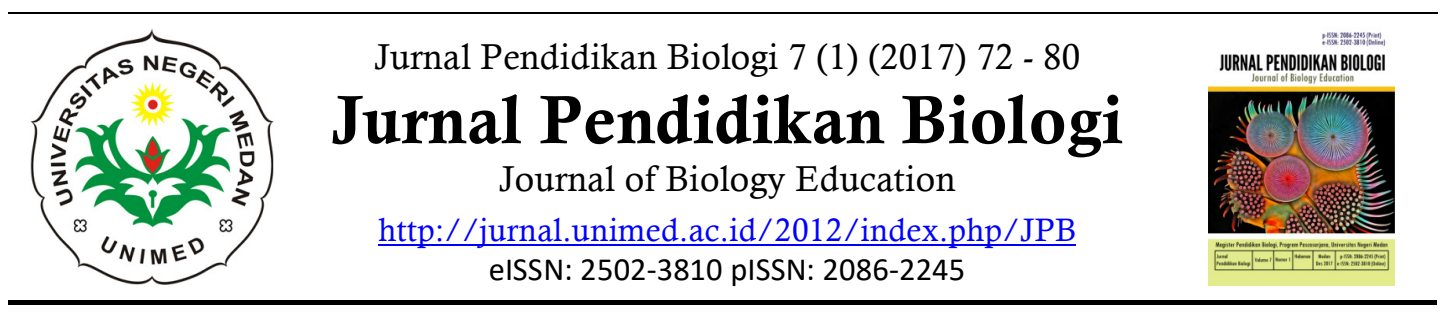

\title{
Hubungan Kemampuan Berpikir Kreatif dan Sikap Terhadap Sains Dengan Literasi Sains Pada Siswa Kelas XI IPA MAN
}

\author{
Azimar Rusdi, Herbert Sipahutar, dan Syarifuddin \\ Program Studi Pendidikan Biologi Program Pascasarjana, Universitas Negeri Medan \\ Korespondensi: azimarrusdi86@gmail.com
}

\begin{abstract}
This research was intended to identify the correlation between (1) creative thinking and science literacy and (2) scientific attitude and science literacy in the concept of environment pollution. Sample was consisted of 219 eleventh grade science student of MAN Medan that was taken by cluster random sampling method. This study was encompassed phases preparation, action, and post research. The instrument were included to scientific literacy test, creative thinking test and scientific attitude questionary. The results is indicated that (1) there is positive correlation between creative thinking and science literacy with $r=0.433$ (2) there is positive correlation between science attitude and science literacy with $r=0.363$. (3) there is positive correlation between creative thinking and science attitude with science literacy with $\mathrm{r}=0,59$. This study implies that reading comprehension and science attitude have important role to improve science literacy skill.
\end{abstract}

Keywords: creative thingking, science attitude and science literacy.

\section{PENDAHULUAN}

Peran sains dalam kehidupan masyarakat modern semakin dominan dalam upaya memenuhi kebutuhan pribadi, pekerjaan dan partisipasinya dalam masyarakat. Salah satu tujuan utama pendidikan sains adalah mewujudkan masyarakat yang berliterasi sains (Norris \& Philips, 2003). Literasi sains merupakan kemampuan untuk menggunakan pengetahuan ilmiah mengidentifikasi pertanyaan dan menarik kesimpulan berdasarkan fakta dan data untuk memahami alam semesta dan membuat keputusan dari perubahan yang terjadi karena aktivitas manusia (OECD, 2003). Literasi ini dapat terwujud jika pendidikan sains mampu melahirkan siswa yang mampu berpikir logis, berpikir kritis dan kreatif, mampu memecahkan masalah, menguasai teknologi serta adaptif terhadap perubahan dan perkembangan zaman.

Skor literasi sains siswa Indonesia untuk kemampuan memahami metode inkuiri dan menginterpretasi data adalah 45,6 pada tahun 2000, 46,4 tahun 2003, dan 47,1 tahun 2006 (PISA, 2009). Secara Internasional skala kemampuan literasi sains dibagi menjadi 6 level. Distribusi siswa Indonesia untuk masing-masing level adalah level 1(41,3\%), level $2(27,5 \%)$, level $3(9,5 \%)$, dan level $4(1,4 \%)$ dan tidak ada siswa Indonesia yang berada pada level 
5 dan level 6 (Awalludin, 2007). Hal ini berarti sebanyak $41,3 \%$ siswa Indonesia hanya memiliki pengetahuan ilmiah terbatas untuk mampu mempresentasikan penjelasan ilmiah dari fakta yang diberikan secara jelas dan eksplisit dan hanya 27,5\% yang memiliki pengetahuan ilmiah memadai untuk memberikan penjelasan dalam konteks yang familiar atau membuat kesimpulan berdasarkan pengamatan sederhana.

Firman (2007) menyatakan bahwa salah satu penyebab rendahnya literasi sains siswa Indonesia adalah kurangnya pembelajaran yang berbasis proses sains. Berdasarkan hasil penilaian PISA kompetensi sains siswa pada aspek mengidentifikasi masalah ilmiah berturutturut tahun 2000, 2003, 2006, dan 2009 menunjukkan nilai relatif tetap dan rendah yaitu 0,$35 ; 0,27 ; 0,31 ; 0,30$. Pada aspek kompetensi menjelaskan fenomena ilmiah menunjukkan nilai semakin rendah, yaitu 0,$40 ; 0,43 ; 0,37 ; 0,37$. Sedangkan jawaban siswa pada soal-soal kompetensi menggunakan bukti ilmiah masih tetap rendah yaitu 0,$34 ; 0,30 ; 0,33 ; 0,34$ (Hadi dan Mulyatiningsih, 2009). Berdasarkan data yang diperoleh kemampuan literasi sains peserta didik Indonesia masih di bawah rata-rata dalam skala pengukuran PISA.

Disamping literasi sains, Pendidikan sains seharusnya membekali siswa dengan keterampilan berpikir kreatif. Selama ini upaya mengembangkan kemampuan berpikir kreatif belum menjadi fokus dan perhatian para pendidik sains (Sudarma, 2013). Hasil penelitian yang dilakukan oleh Trend International Mathematics Science tahun 2007 menunjukkan bahwa nilai rata-rata sains siswa pada kemampuan penalaran adalah 438 yang berada di bawah skor ratarata TIMSS yaitu 500 .

Proses sains merujuk pada proses mental ketika menjawab suatu pertanyaan atau memecahkan masalah. Dalam merencanakan pemecahan suatu masalah diperlukan kemampuan berpikir kreatif untuk mengorganisasikan informasi atau data-data yang ada serta menentukan strategi tertentu untuk menemukan penyelesaian. Krulik (Siswono, 2005) menyatakan bahwa dalam merencanakan penyelesaian masalah diperlukan suatu kemampuan berpikir kreatif yang memadai, karena berpikir kreatif merupakan proses berpikir yang menghasilkan bermacammacam jawaban. Awaludin (2007) juga menyatakan berpikir kreatif merupakan kemampuan dalam menyelesaikan masalah dan mengembangkan ide-ide dengan cara yang berbeda. Oleh karena itu, berpikir kreatif perlu diterapkan dalam setiap kegiatan proses ilmiah agar siswa dapat menentukan cara terbaik untuk mengemukakan penemuan dan penjelasan mereka.

Upaya pembaharuan pendidikan sains selama ini belum sepenuhnya mengembangkan dimensi sikap terhadap sains (Mullis, 2009). Dalam pembelajaran, sikap dapat didefenisikan sebagai kecenderungan siswa untuk suka atau tidak suka terhadap komponen-komponen belajar seperti guru, materi, tugas, dan lain sebagainya. Azwar (2013) menyatakan bahwa sikap seseorang terhadap suatu objek adalah perasaan mendukung atau memihak pada objek tertentu.

Sikap sering digunakan dalam mendiskusikan masalah-masalah dalam pendidikan sains. Dua kategori yang dapat dibedakan adalah "sikap terhadap sains" dan "sikap sains". Sikap terhadap sains lebih menekankan kepada minat terhadap sains. Minat terhadap sains dapat didefenisikan sebagai suatu keadaan dalam diri siswa yang menunjukkan pemusatan perhatian terhadap sains, baik dalam proses pembelajaran dan materi sains.

Pemilihan tema pencemaran lingkungan dalam konten literasi sains didasarkan pada banyaknya masalah lingkungan dan 
fenomena alam yang dapat ditemukan langsung dalam kehidupan siswa sehingga siswa dapat memahami dan menjelaskan fenomena alam serta mengaitkan perubahan yang terjadi pada alam dengan aktivitas yang dilakukan dalam kehidupan sehari-hari. Tujuan penelitian ini adalah untuk melihat secara empirik hubungan antara kemampuan berpikir kreatif dan sikap terhadap sains dengan literasi sains siswa kelas XI IPA MAN.

\section{METODE}

Penelitian ini dilaksanakan pada bulan September 2015 sampai Maret 2016 di tiga sekolah MAN di kota Medan, yaitu MAN 1, MAN 2, dan MAN 3 Medan. Populasi penelitian ini adalah seluruh siswa kelas XI IPA MA Negeri Medan (612 siswa), yang terdistribusi pada MAN 1 (229 siswa), MAN 2 (224 siswa), dan MAN 3 (159 siswa). Sampel diambil dengan cara cluster random sampling, diperoleh dua kelas persekolah yaitu XI IPA 3 dan XI IPA 5 (sebanyak 70 siswa MAN 1), kelas XI IPA 4 dan XI IPA 6 (sebanyak 73 siswa MAN 2), kelas XI IPA 3 dan XI IPA 5 (sebanyak 76 siswa, MAN 3).
Instrumen yang digunakan instrumen tes penilaian literasi sains menyerupai soalsoal pada literasi sains PISA 2009. Instrumen tes penilaian kemampuan berpikir kreatif dibuat berdasarkan petunjuk yang diberikan oleh Munandar (2009). Data diperoleh dengan teknik pemberian tes dan nontes. Instrumen yang dikembangkan ini adalah instrumen tes kemampuan berpikir kreatif verbal serta angket sikap siswa terhadap sains diadaptasi dari instrumen sikap sains yang diselenggarakan PISA.

Data hasil penelitian dianalisis dengan teknik korelasi, regresi, kemudian dilanjutkan dengan analisis jalur pada taraf signifikansi $\alpha=0,05$, menggunakan SPSS versi 21.0.

\section{HASIL PENELITIAN}

Hubungan kemampuan berpikir kreatif dan sikap terhadap sains dengan Literasi Sains Siswa pada masing-masing sekolah

Data yang diperoleh dari 219 responden (6 kelas), diperoleh tingkat korelasi kemampuan berpikir kreatif dan sikap terhadap literasi sains tertinggi terdapat di sekolah MAN $1(0,76)$ dan $(0,6)$ dengan kriteria hubungan kuat.

Tabel 1. Nilai Berpikir kreatif dan sikap terhadap sains

\begin{tabular}{llccc}
\hline \multirow{2}{*}{ No } & \multirow{2}{*}{ Hubungan antar variabel } & MAN 1 & MAN 2 & MAN 3 \\
\cline { 3 - 5 } & & $\mathbf{r}$ & $\mathbf{R}$ & $\mathbf{r}$ \\
\hline 1 & BK dan Literasi & 0,76 & 0,54 & 0,34 \\
2 & Sikap dan Literasi & 0,6 & 0,06 & 0,091 \\
\hline
\end{tabular}

*) BK: Berpikir kreatif

*) r: Nilai korelasi antara berpikir kreatif, sikap terhadap sains dengan literasi sains.

Hubungan Kemampuan Berpikir Kreatif dengan Literasi Sains

Berdasarkan hasil analisis jalur diketahui bentuk hubungan antara kemampuan berpikir kreatif $\left(\mathrm{X}_{1}\right)$ dengan literasi sains $(\mathrm{Y})$ digambarkan dengan persamaan $\hat{\mathrm{Y}}=31.6+0,6\left(\mathrm{X}_{1}\right)$ berkorelasi sedang $(\mathrm{r}=0,557)$. (Gambar 1). Dari hasil analisis hipotesis koefisien arah regresi antara kemampuan berpikir kreatif dengan literasi sains sebesar 0,56. nilai koefisien kontribusi $\left(\mathrm{R}^{2} \mathrm{xy}\right)$ adalah 0,31 sehingga 
kontribusi kemampuan berpikir kreatif MAN Medan sebesar 31\%. terhadap literasi sains siswa kelas XI IPA

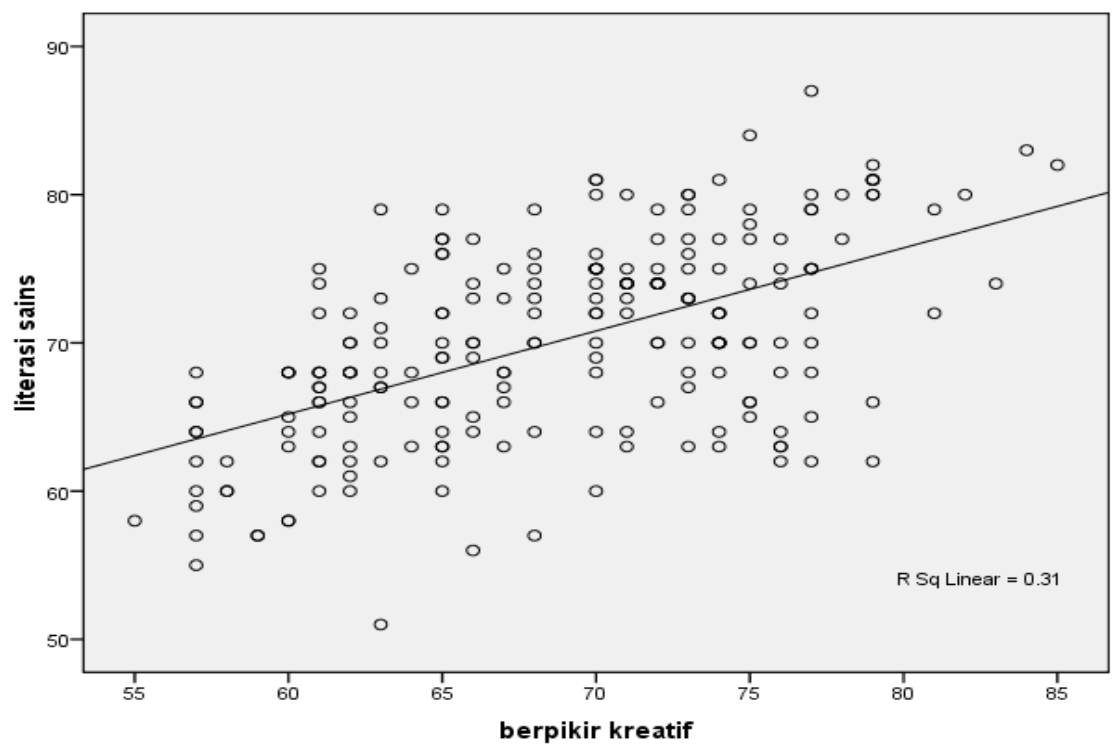

Gambar 1. Hubungan Kemampuan Berpikir kreatif $\left(\mathrm{X}_{1}\right)$ dengan literasi sains $(\mathrm{Y})$

$$
\left(\hat{\mathrm{Y}}=31.577+0,56 \mathrm{X}_{1} ; \mathrm{R}^{2} \mathrm{x}_{1} \mathrm{y}=0,31\right)
$$

Hubungan Sikap terhadap Sains dengan sains $\left(\mathrm{X}_{2}\right)$ dengan literasi sains $(\mathrm{Y})$ Literasi Sains digambarkan dengan persamaan $\hat{Y}=46.3$

Berdasarkan hasil analisis jalur $+0,3\left(\mathrm{X}_{2}\right)$ berkorelasi rendah $(\mathrm{r}=0,36)$ diketahui hubungan antara sikap terhadap (Gambar 2).

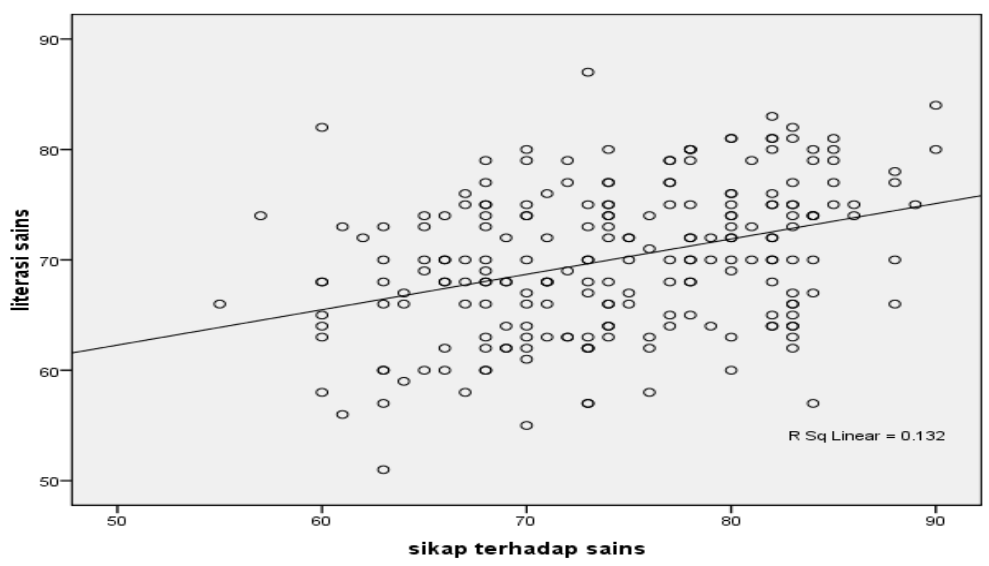

Gambar 2. Hubungan Sikap terhadap Sains $\left(\mathrm{X}_{2}\right)$ dengan Literasi Sains $(\mathrm{Y})$ $\left(\hat{Y}=46,258+0,321 X_{2} ; R^{2} x_{2} y=0,132\right)$.

Dari hasil analisis hipotesis diperoleh diperoleh sebesar 0,321 . Sedangkan nilai hasil koefisien arah regresi antara sikap koefisien kontribusi (R2xy) adalah 0,132 terhadap sains dengan literasi sains sehingga kontribusi sikap terhadap sains 
pada literasi sains siswa kelas XI IPA MAN Medan sebesar 13,2\%.

Hubungan Kemampuan Berpikir Kreatif dan Sikap Terhadap Sains dengan Literasi Sains
Berdasarkan hasil analisis jalur diketahui hubungan antara kemampuan berpikir kreatif (X1) dan sikap terhadap sains (X2) dengan literasi sains (Y) digambarkan dengan persamaan $\hat{\mathrm{Y}}=$ $22.574+0,494 \quad(\mathrm{X} 1)+0.182$ (X2) berkorelasi rendah $(\mathrm{r}=0,59)(\mathrm{Gambar} 3)$.

Dependent Variable: literasi

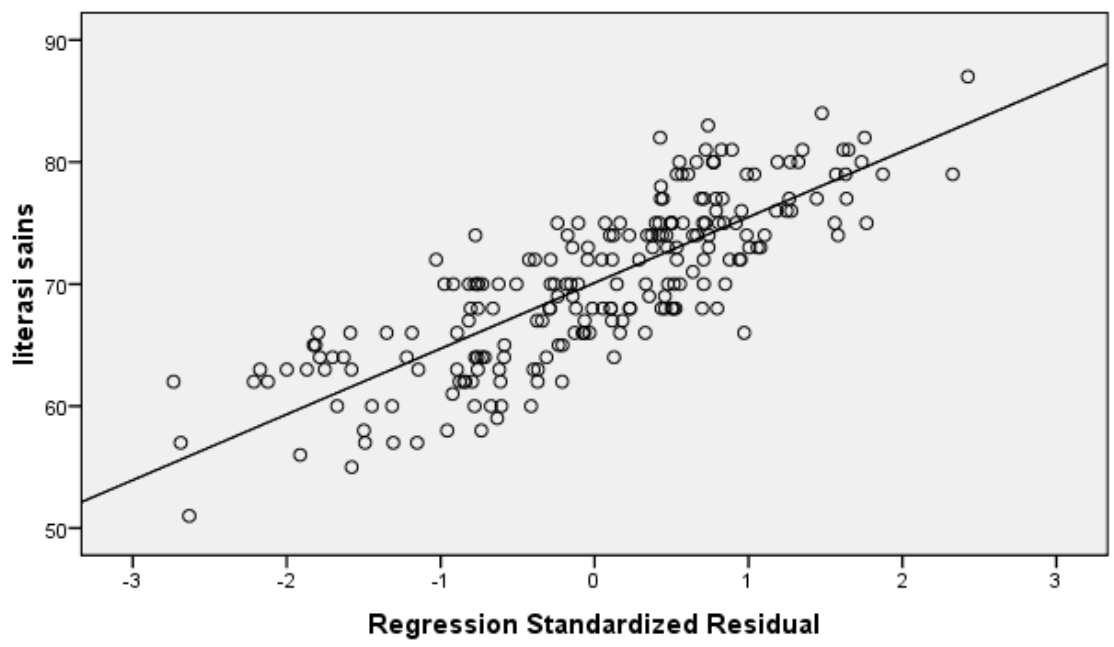

Gambar 3. Hubungan Kemampuan berpikir kreatif $\left(\mathrm{X}_{1}\right)$ dan Sikap terhadap Sains $\left(\mathrm{X}_{2}\right)$ dengan Literasi Sains $(\mathrm{Y})\left(\hat{\mathrm{Y}}=22.574+0,494\left(\mathrm{X}_{1}\right)+0.182\left(\mathrm{X}_{2}\right) ; \mathrm{R}^{2} \mathrm{X}_{1 \mathrm{X} 2} \mathrm{y}=0,35\right)$.

Dari hasil analisis hipotesis diperoleh hasil koefisien arah regresi $b_{1}$ sebesar 0,494, $b_{2}$ sebesar 0,182 . Sedangkan nilai koefisien kontribusi $\left(\mathrm{R}^{2} \mathrm{x}_{1} \mathrm{x}_{2} \mathrm{y}\right)$ adalah 0,35 sehingga

\section{PEMBAHASAN}

\section{Hubungan Kemampuan Berpikir Kreatif dengan Literasi Sains}

Dari hasil analisis hasil penelitian di peroleh bahwa kemampuan membaca pemahaman memiliki korelasi positif dan memberikan kontribusi sebesar 31\% terhadap peningkatan literasi sains siswa.

Dalam literasi sains terdapat aspek proses sains yang merujuk pada kemampuan menjawab atau memecahkan masalah yang termasuk dalam kegiatan kontribusi kemampuan berpikir kreatif dan sikap terhadap sains pada literasi sains siswa kelas XI IPA MAN Medan sebesar $35 \%$.

inkuiri ilmiah dan merupakan komponen penting untuk mengembangkan literasi sains. Pada saat melakukan inkuiri ilmiah diperlukan kemampuan berpikir kreatif yang merupakan kemampuan mendasar dalam kegiatan tersebut (Lederman, 2013).

Rustaman (2011) mengemukakan bahwa literasi sains adalah kemampuan seseorang untuk memahami sains, mengkomunikasikan sains (lisan dan tulisan), serta menerapkan pengetahuan sains untuk memecahkan masalah sehingga memiliki sikap dan kepekaan yang tinggi terhadap diri dan lingkungannya dalam 
mengambil keputusan berdasarkan pertimbang-pertimbangan sains. Dengan demikian peserta didik tentunya harus memiliki kemampuan berpikir kreatif untuk dapat memahami sains.

Dengan melakukan inkuiri ilmiah, seseorang dapat berpikir dan bertindak serta mengembangkan metode secara kreatif sehingga diperoleh suatu hal baru yang lebih baik dan bermanfaat bagi kehidupan. Munandar (2009) menyatakan berpikir kreatif merupakan kemampuan untuk melihat bermacam-macam kemungkinan penyelesaian terhadap suatu masalah.

Proses berpikir kreatif merupakan kemampuan berpikir tingkat tinggi yang mengkombinasikan berpikir logis dan berpikir divergen. Berpikir divergen digunakan untuk mencari ide-ide dalam menyelesaikan masalah secara ilmiah, sedangkan berpikir logis digunakan untuk memverifikasi ide-ide tersebut menjadi sebuah penyelesaian yang baik. Hal ini sesuai dengan pendapat Yuli (2005) bahwa berpikir kreatif merupakan kemampuan untuk memahami masalah dan menemukan penyelesaian dengan strategi atau metode yang bervariasi.

Dalam kompetensi sains terdapat kegiatan mengidentifikasi masalah ilmiah yang melibatkan kemampuan dalam mengenali suatu masalah. Beberapa pertanyaan yang diberikan berkaitan dengan sebuah masalah dan diminta untuk diidentifikasi pemecahan masalahnya. Kemampuan mengidentifikasi masalah ilmiah menuntut keterampilan dalam berpikir, salah satunya adalah berpikir kreatif. Berpikir kreatif berarti memiliki pemikiran yang fleksibel terhadap berbagai kemungkinan variabel yang melekat pada suatu fenomena. Fleksibilitas ini menjadikan seseorang bersifat terbuka terhadap berbagai pengalaman sehingga menjadi peka terhadap permasalahan dari suatu fenomena ( Syafii, 2011).

Kemampuan dalam menjelaskan fenomena ilmiah dapat diperoleh dengan memiliki pengetahuan yang luas dan kemampuan analisis yang baik dan kreatif. Jawaban kreatif yang dikemukakan akan muncul saat seseorang mampu berpikir secara divergen dan konvergen. Aktamis \& Ergin (2008) menambahkan bahwa ilmuan yang kreatif akan sangat lebih sensitif jika dihadapkan pada sebuah masalah. Masalah yang diberikan juga harus berkaitan dengan kehidupan secara nyata dan bukan sesuatu yang abstrak.

Pencemaran lingkungan merupakan masalah yang semakin penting untuk diselesaikan karena menyangkut keselamatan, kesehatan, dan kehidupan manusia. Untuk menyelesaikan masalah pencemaran lingkungan, diperlukan beberapa kompetensi seperti kemampuan mengidentifikasi sumber pencemar, menjelaskan bagaimana proses pencemaran itu terjadi dan bagaimana langkah penyelesaian pencemaran lingkungan itu sendiri. Dalam kompetensi tersebut diperlukan kemampuan berpikir kreatif yang merupakan salah satu kemampuan mendasar dan perlu dimiliki oleh setiap orang dalam menyelesaikan permasalahan lingkungan saat ini (Nastuti, 2015). Dengan pemikiran yang kreatif, seseorang akan mampu memberikan kontribusi untuk mengembangkan ilmu pengetahuan dan teknologi serta menghasilkan gagasangagasan yang bervariasi sehingga dapat membantu dalam memperbaiki masalahmasalah yang ditimbulkan akibat pencemaran lingkungan.

\section{Hubungan Sikap terhadap Sains dengan Literasi Sains}

Dari hasil analisis penelitian di peroleh bahwa sikap terhadap sains berhubungan positif dengan literasi sains siswa dan 
memberikan kontribusi sebesar 13,2\%. Sikap terhadap sains secara keseluruhan menggambarkan bahwa siswa telah memiliki ketertarikan terhadap sains dengan baik. Sikap terhadap sains merupakan salah satu bagian penting untuk menghasilkan siswa yang mampu berpikir secara ilmiah seperti perilaku yang dilakukan oleh seorang ilmuwan seperti mencari jawaban dari pertanyaan (mengumpulkan berbagai sumber) dan menyimpulkan dari jawaban-jawaban yang ditemukan. Hal ini sesuai dengan konsep literasi sains yaitu, kemampuan dalam memahami, mengkomunikasikan, serta mengaplikasikan konsep sains dalam kehidupan nyata.

Hal ini juga diperkuat dengan pernyataan Ali (2013) yang menjelaskan bahwa sikap terhadap sains sangat penting bagi prestasi siswa karena sikap dan prestasi mengarahkan siswa pada pemilihan karir, penggunaan pemahaman konsep dan metode ilmiah dalam kehidupan mereka. Siswa yang mempunyai sikap positif terhadap pelajaran sains akan cenderung lebih tekun dalam belajar sehingga memengaruhi keberhasilan siswa dalam bidang sains dan memperoleh prestasi yang baik.

Sikap terhadap sains dalam penelitian ini adalah ketertarikan terhadap sains. Adodo (2013) menyatakan bahwa aspek ketertarikan dapat memengaruhi perhatian dan meningkatkan memori dengan baik. Ketika seseorang sedang merasa tertarik terhadap suatu hal, maka ia akan memberikan perhatian pada hal tersebut. seseorang akan bersikap dan bertindak untuk selalu mengetahui lebih mendalam dan meluas dari apa yang dipelajarinya, dilihat, dan didengar Sulistiawati (2015). Ketertarikan terhadap sains menunjukkan bagaimana kesukaan seseorang terhadap sains, seperti ketertarikan mempelajari sains, bercerita mengenai sains, menonton program sains dan minat terhadap mata pelajaran sains (Zanaton, 2006).

Sikap terhadap sains menunjukkan minat dalam ilmu pengetahuan dan motivasi untuk bertindak secara bertanggung jawab pada lingkungan. Sikap terhadap sains menunjukkan ketertarikan dan tanggap terhadap isu-isu sains dan teknologi yang memengaruhi kehidupan manusia. Sikap terhadap sains merupakan kecenderungan seseorang untuk memberikan respon berdasarkan ilmu yang telah diakui kebenaranya untuk memecahkan suatu masalah (Damanik dan Bukit 2013). Hal ini berkaitan dengan prinsip literasi sains yaitu, menemukan, mencari, dan menyimpulkan sebuah permasalahan. Ketertarikan terhadap isu sains akan mendorong siswa berusaha untuk memecahkan permasalahan terutama yang berkaitan dengan masalah lingkungan sehingga siswa peduli dan bertanggung jawab terhadap kualitas lingkungan sekitarnya.

\section{Hubungan Kemampuan Berpikir Kreatif dan Sikap Terhadap Sains dengan Literasi Sains}

Dalam melakukan keterampilan proses sains diperlukan kemampuan berpikir kreatif untuk mencari penyelesaian terhadap suatu masalah dengan strategi atau metode yang bervariasi. Sikap positif terhadap sains melatih seseorang untuk mengerjakan banyak tugas yang dapat meningkatkan kemampuan berpikir kreatif. Hoolbrok dan Rannikmae (2009) menyatakan bahwa literasi sains mencakup kemampuan untuk menggunakan pengetahuan dan keterampilan ilmiah dengan pemikiran yang kreatif. Keterampilan ilmiah perlu dikembangkan melalui pengalaman langsung dan sikap positif terhadap sains dengan memperhatikan peristiwa alam, selalu ingin mengetahui apa, bagaimana, dan mengapa tentang 
suatu gejala alam agar mampu mengambil keputusan berdasarkan pertimbangan sains untuk kebaikan diri.

\section{SIMPULAN}

Berdasarkan hasil dan pembahasan, dapat diambil simpulan sebagai berikut : (1) Terdapat hubungan positif antara kemampuan berpikir kreatif dengan literasi sains siswa kelas XI IPA MAN Medan pada materi pencemaran lingkungan pada kategori sedang $(\mathrm{r}=0,56)$ dengan kontribusi sebesar $31 \%$. (2) Terdapat hubungan positif antara sikap terhadap sains dengan literasi sains pada materi pencemaran lingkungan siswa kelas XI IPA MAN Medan pada kategori rendah $(\mathrm{r}=0,36)$ dengan kontribusi sebesar $13,2 \%$. (3) Terdapat hubungan positif antara kemampuan berpikir kreatif dan sikap terhadap sains dengan literasi sains pada materi pencemaran lingkungan siswa kelas XI IPA MAN Medan pada kategori sedang $(\mathrm{r}=$ 0,59 ) dengan kontribusi sebesar 35\%.

\section{DAFTAR PUSTAKA}

Adodo, S. O. 2013. Correlate of Pre-Service Teachers and In-Service Teachers Perceived and Priorotized Students' Psychological Profiles for the Teaching and Evaluating Basic Science and Technology (BST). Journal of Emerging Trends in Engineering and Applied Sciences. Vol.4, No.2 : 305-310.

Aktamis, H \& Ergin, O. 2008. The Effect of Scientific Process Skill Education on Students' Scientific Creativity, Science Attitudes and Academic Achievements. Asia-Pasific Forum on Science Learning and Teaching. Vol. 9, No.1: 1-20.

Ali, M.S. 2013. Attitude Towards Science and its Relationship with Student's Achievement in Science. Interdisciplinary Journal of Contemporary Research in Business, Vol 4,No $10: 707-718$.

Anwar, M.N., Muhammad, A., Asma, K., Muhammad, N., Gulam, M. 2012. Relationship of Creative Thinking with The Academic Achievement of Secondary
School Students. International Interdisciplinary Journal of Education, vol 1, No 3 : 44-47

Azwar, Saifuddin. 2013. Sikap Manusia : Teori dan Pengukurannya, edisi kedua. Yogyakarta : Pustaka Belajar

Damanik. DP., \& N Bukit. 2013. Analisis Kemampuan Berpikir Kritis dan Sikap Ilmiah pada Pembelajaran Fisika Menggunakan Model Pembelajaran Inquiry Training (IT) dan Direct Instruction (DI): Jurnal Pendidikan Fisika Program Pascasarjana Universitas Negeri Medan. Vol.2. No.1.

Ekohariadi. 2009. Faktor-Faktor Yang Mempengaruhi Literasi Sains Siswa Indonesia Berusia 15 Tahun. Jurnal Pendidikan Dasar. Vol.10 No 1: 28-41

Firman, H. 2007. Analisis Literasi Sains Berdasarkan Hasil PISA Nasional Tahun 2006. Jakarta: Pusat Penilaian Pendidikan Balitbang Depdiknas.

Hadi, S., Mulyatiningsih , E. 2009. Model Trend Prestasi Peserta didik Berdasarkan Data PISA Tahun 2000, 2003, dan 2006. Makalah Seminar Mutu Pendidikan Dasar dan Menengah Hasil Penelitian Puspendik. Jakarta.

Krulik, Stephen \& Rudnick, Jesse A. 1995. The New Sourcebook for Teaching Reasoning and Problem Solving in Elementary School. Needham Heights, Massachusetts: Allyn \& Bacon

Lederman, N.G. 2013. Nature of science and scientific inquiry as contexts for the learning of science and achievement of scientific literacy. International. Journal of Education in Mathematics, Science and Technology. Vol.1, No.3: 138-147.

Munandar, Utami. 2009. Pengembangan Kreativitas Anak Berbakat. Jakarta: Rineka Cipta

Nastuti, Dwi.,\& Husen. 2015. Peningkatan Kemampuan Berpikir Kreatif Siswa Melalui Penerapan Model Problem Based Learning. Jurnal Bioedukasi. Vol 3. No.2.

Norris S.P., \& Phillips, L.M. 2003. How literacy in its fundamental sense is central to scientific literacy. Science Education. Vol.8, No.7: 224-240.

OECD. 2007. Pisa 2006: Science Competencies For Tomorrow's World, Volume 1-Analyses. Paris. (Online),

(http://www.oei.es/evaluacioneducativa/in formePISA2006-FINALLingles.pdf, diaskses 12 Januari2015). 
OECD. 2003. Chapter 3 of the Publication "PISA 2003 Assesment of framework - mathematics, Reading, Science and Problem Solving Knowledge and Skills. (Online). (http://www.oecd.org /dataoecd/38/29/33707226.pdf. November 2014).

Osgood, C.E., Suci, G.J. 1975. The Measurement of Meaning. Urbana, Chicago: University of Illinois Press.

Rustaman. 2011. Membangun Literasi Sains Peserta Didik. Bandung: Humaniora.

Sadler,T.D. 2004. Informal Reasoning Regarding Socioscientific Issues : A Critical Review of Research. Journal of Research in Science Teaching, Vol.41, No.5 : 513-536.

Siswono, Eko., Tatag, Yuli. 2005. Upaya Meningkatkan Kemampuan Berpikir Kreatif Siswa Melalui Pengajuan Masalah. Jurnal Pendidikan Matematika dan Sains. Universitas Negeri Yogyakarta. (Online), Tahun X, No. 1 , Juni 2005,(https://tatagyes.files.wordpress.com/ 2009/11/paper05_problemposing.pdf, diakses 12 Februari 2015)

Smarabawa, Ib Arnyana, Igan, Setiawan. 2013. Pengaruh Model Pembelajaran Sains Terhadap Masyarakat Terhadap Pemahaman Konsep Biologi Dan Keterampilan Berpikir Kreatif Siswa. E-
Jurnal Program Pascasarjana Universitas Pendidikan Ganesha. (Online), Volume 3 Tahun 2013. (pasca.undiksha.ac.id/ejournal/index.php/jurnal_ipa/article/.../54 1 diakses, 15 Januari 2015.

Sulistiawati. 2015. Analisa Pemahaman Literasi Sains Mahasiswa yang Mengambil Mata Kuliah IPA Terpadu Menggunakan Contoh Soal Pisa 2009. Journal of sainteks, 12(1)

Tjalla, Awalluddin. 2007. Potret Mutu Pendidikan Indonesia Ditinjau Dari HasilHasil Studi Internasional.(Online).(http://Pustaka.Ut.A c.Id/Pdfartikel/Tig601.Pdf diakses, Oktober 2014)

Toharuddin, Uus., Sri, H., Andrian, R. 2011. Membangun Literasi Sains Peserta Didik. Bandung : Humaniora.

Wan Syafi'i, Evi Suryawati, Ardityas Robi Saputra. 2011. Kemampuan Berpikir Kreatif dan Penguasaan Konsep. Jurnal Biogenesis. Vol 8. No 1.

Yager, R.E., Enger,S.K. 1998. The Iowa Assessment Handbook, The Iowa Science Education Centre at University of Lowa.

Zanaton, Ikhsan., 2006. Sikap Terhadap Sains dalam Kalangan Pelajar Sains Peringkat Menengah dan Matrikulasi. Jurnal Pendidikan ISSN: 0128-7702. Universitas Kebangsaan Malaysia. Selangor. 